\title{
Unique Morphology of Intraoperative Measurement of Distal Femur in Northern Malaysian Females and its Correlation with Total Knee Arthroplasty Implant Sizing
}

\author{
Morfología Única de la Medición Intraoperatoria del Fémur Distal en Mujeres del Norte de \\ Malasia y su Correlación con el Tamaño del Implante en Artroplastia Total de Rodilla
}

Shaifuzain Ab Rahman'; Sanjeevan Radhakrishnan'; AmranAhmed Shokri'; Muhammad Rajaei Ahmad'; Ahmad Filza Ismail ${ }^{2}$; Hairul Anuar Hashim³ ${ }^{3}$ \& Tengku Muzaffar ${ }^{1}$

\begin{abstract}
AB RAHMAN, S.; RADHAKRISHNAN, S.; SHOKRI, A. A.; AHMAD, M. R.; ISMAIL, A. F.; HASHIM, H. A. \& MUZAFFAR, T. Morphology of intraoperative measurement of distal femur in Northern Malaysian females and its correlation with total knee arthroplasty implant sizing. Int. J. Morphol., 39(1):192-197, 2021.

SUMMARY: Accurate implant sizing is one of the major determinants in defining the success of total knee arthroplasty (TKA). Current TKA implants are based on Caucasian knee morphometry which is well documented to be larger than Asian knees. Even more, with regards to sizing, implant mismatch tends to be more evident in the female population. This study was designed to evaluate the distal femur dimensions of Malaysian female patients who underwent TKA in our institution and to compare them with the current prosthetic system in use. A total of 199 female patients (207 knees) who underwent TKA were enrolled in this study. Intraoperatively, the AP dimensions (medial and lateral condyles) and mediolateral (ML) width were measured. Known dimension of the femoral component of the prosthetic knee system currently in use were compared with the morphological data. The average femoral component overhang was $2.11 \mathrm{~mm}$ (SD $3.94 \mathrm{~mm}$ ). There was significant difference between the mean ML width of the resected femur and the femoral component $(\mathrm{p}<0.01)$. Analysis also revealed a significant positive and weak relationship between both, AP (medial and lateral) and ML dimension. The aspect ratio (ML/AP) of the native femur was generally smaller than the implant aspect ratio which is likely to cause overhang in our population. In general, this study shows that the knees of our female sub-population are even narrower than the other Asian female knees from previous studies. Implants should be designed based on the morphological data of the local population. Implant manufactures should tailor them to accommodate a smaller change in ML width for an increment in the AP length and provide several ML widths for one AP length to obtain a better fitting prosthesis hence curbing the problem of ML overhang.
\end{abstract}

KEY WORDS: Morphometric measurement; FemaleMalaysian knees; Total knee arthroplasty; Knee dimensions.

\section{INTRODUCTION}

One of the major crucial factors to the success of total knee arthroplasty (TKA) is correct sizing. Thus, to avoid complications and maximize the outcome of the surgery, proper implant sizing is of utmost importance (Hitt et al., 2003).

Implant mismatch be it in the medio-lateral (ML) dimension or antero-posterior (AP) dimension, is of a great clinical impact to the outcome of TKA. Medio-lateral overhang or oversizing could result in soft tissue irritation and affect balancing efforts (Hitt et al.). On the other hand, under sizing could leave the exposed cancellous bone which may be a source of immediate postoperative bleeding (Hitt et al.). A precise AP dimension is important to maintain flexionextension gap (Thilak \& George, 2016) whereas anterior notching predisposes to periprosthetic fractures (Lonner et al., 2008).

The currently used TKA implants worldwide are based on morphometric measurements obtained from Caucasian population. However, studies have shown that Asian femurs are narrower than the whites (Vaidya et al., 2000; Urabe et al., 2008; Chin et al., 2011; Yue et al., 2011). It is also well documented that females had a narrower distal femur (Chin et al., 2002; Lonner et al.; Ewe et al., 2009; Chin et al.,

\footnotetext{
${ }^{1}$ Department of Orthopedic, Hospital Universiti Sains Malaysia,16150 Kubang Kerian, Kelantan, Malaysia.

${ }^{2}$ Department of Community Medicine Hospital Universiti Sains Malaysia,16150 Kubang Kerian, Kelantan, Malaysia

${ }^{3}$ Department of Sport Medicine, Hospital Universiti Sains Malaysia, 16150 Kubang, Kerian, Kelantan, Malaysia.
} 
2011) and morphologically, knees of Asian females significantly differ from their Caucasian counterparts (Vaidya et al.; Urabe et al.; Yue et al.).With regards to sizing, implant mismatch tends to be more evident in the female population (Vaidya et al.; Hitt et al.; Ewe et al.; Cheng et al., 2009). In our centre, Hospital UniversitiSains Malaysia, majority of patients undergoing TKA are females accounting to about $86 \%$ (Ismail et al., 2016). Thus, the question of implant mismatch in our population is of great value.

Globally, there are many morphological studies ranging from cadaveric studies to radio-imaging studies using Computed Tomography (CT) or Magnetic Resonance (MR) imaging of normal patients not requiring surgery (Seedhom et al., 1972: Cheng et al.; Yue et al.; Magetsari et al., 2015).The present study was designed to obtain a direct intraoperative morphological data on osteoarthritic knees that are usually different from the normal knees.

This study was designed to evaluate the distal femur dimensions of female patients who underwent TKA in our institution and to compare them with the currently used prosthetic system at our center. The authors believe the results of this study could provide a guide to implant manufacturers to tailor better fitting prosthesis which suit the morphometric measurements of the Malaysian population especially in female patients hence optimizing the outcome of TKA and reducing its complications.

\section{MATERIAL AND METHOD}

This is a single centre observational cross-sectional study with all procedures performed by two experienced arthroplasty surgeons. This study was approved by the Human Ethical Committee of the School of Medical Sciences, Universiti Sains Malaysia. A total of 199 female patients (207 knees) who underwent primary total knee arthroplasty for osteoarthritis at the arthroplasty unit of Hospital UniversitiSains Malaysia were randomly included in this study in accordance to the study inclusion and exclusion criteria. This study was conducted from January 2017 until December 2018.

Patients with congenital or acquired deformities of the knee or with history of disease/trauma involving the knee, gross deformities of the knee of more than 15 degrees valgus/ varus or severe fixed flexion deformity more than 20 degrees were excluded from this study. Patients with substantial bone loss and/or degeneration requiring augmentation or presence of anterior notching or severe flexion gap laxity after distal femoral cut were also excluded.
All TKAs were performed by one of the two senior arthroplasty surgeons at our institution. After removal of osteophytes, the distal femoral cuts were performed prior to making measurements in millimeters using a sterile surgical caliper. All measurements were taken by the operating surgeon to reduce random error. Measurement of the distal femur after the distal cut is considered a reasonable approach as it would be easier to place a ruler on the cut surfaces and minimizing tilting of the tool that would potentially occur on an uncut distal femur (Lonner et al.). The distal cut was made nine $\mathrm{mm}$ from the medial joint line which is a minimum cut required for the TKA prosthesis currently used in our center. The anterior cut was performed using an anterior referencing cutting guide to ensure the cut was flushed with the femoral shaft in order to avoid anteriornotching.

The dimensions measured from the resected distal femur (Fig. 1) were the anteroposterior dimensions of the medial (APM) and lateral femoral condyles (APL) and the mediolateral (ML) width. The APM and APL were taken as the maximum distance of a line perpendicular to the transepicondylar axis (TEA). MLwidth was measured as the distance between the medial and lateral cortex along the TEA. After appropriate sizing and bone cuts, the implant size which closely approximated the anteroposterior dimension of the resected femur were then implanted. Morphological data of the distal femur were recorded into the study proforma. Aspect ratios which measure the shape of the distal femur in (ML/ AP) and also in (AP/ML) are calculated separately for both the medial and lateral femoral condyles. Data about the

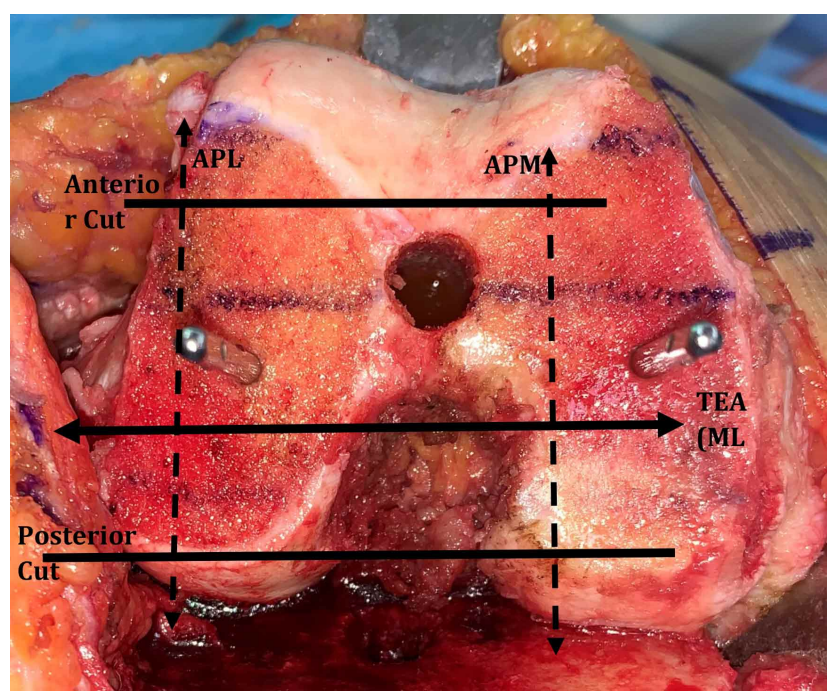

Fig. 1. Intraoperative photograph showing the dimension of the distal femur after distal bone resection and removal of osteophytes. APM: Anterior posterior dimension of the medial femoral condyle; APL: Anterior posterior dimension of the lateral femoral condyle; ML width: Mediolateral width along the transepicondylar axis) The APM and APL were taken at the maximum length of the condyle perpendicular to the transepicondylar axis (TEA). 
anteroposterior (AP) and mediolateral (ML) dimensions of the present femoral components used were obtained from the respective implant manufacturer.

The data were analyzed using SPSS version 24 . The dimensions are summarized as the mean and standard deviation. Correlation between AP and ML dimensions of the patient's femur were determined using Pearson correlation. As the implant size were determined by the close approximation of AP dimension of the resected femur, thus the difference of the mean ML dimension between the implant and patient's knee were determined. The differences between the component ML and femoral ML were assessed using paired t-test with a confidence interval set at $95 \%$ and a p-value of less than 0.05 were regarded as statistically significant.

\section{RESULTS}

There were total of 199 female patients involved in this study with a mean age of 64.3 years old (SD: 5.7). Eight (8) patients had bilateral total knee arthroplasty making it up to a total of 207 knees included into this study. The ethnic distribution of the patients was predominantly Malay accounting to $97 \%$ of the total followed by Chinese (2\%) and Indian (1\%).

The mean AP medial (APM) of the resected femur was $66.02 \mathrm{~mm}$ (SD: 3.53) while the mean AP lateral (APL) was $68.08 \mathrm{~mm}$ (SD: 3.44). The mean mediolateral (ML) width of the measured femur was $59.71 \mathrm{~mm}$ (SD: 4.42). The calculated mean aspect ratio as determined by ratio of ML to APM and APL were 0.91 and 0.88 , respectively. A summary of the intraoperative data of the resected distal femurs is shown in Table I.

Table I. Intraoperative measurements of the distal femur of female TKA patients and their calculated aspect ratios $(n=207)$

\begin{tabular}{lll}
\hline Dimensions measured & Mean (SD) & Range \\
\hline AP (mm) & & \\
$\quad$ Medial & $65.74(3.63)$ & $57.30-74.90$ \\
$\quad$ Lateral & $67.86(3.44)$ & $58.80-75.50$ \\
ML (mm) & $59.61(4.33)$ & $50.00-70.00$ \\
ML/AP (aspect ratio) & & \\
$\quad$ Medial & $0.91(0.06)$ & $0.73-1.06$ \\
$\quad$ Lateral & $0.88(0.06)$ & $0.72-1.03$ \\
* AP/ML (aspect ratio) & & \\
$\quad$ Medial & 1.11 & $0.94-1.36$ \\
$\quad$ Lateral & 1.13 & $0.99-1.39$ \\
\hline
\end{tabular}

$\mathrm{AP}=$ Anteroposterior; $\mathrm{ML}=$ mediolateral $; \mathrm{SD}=$ standard deviation. ${ }^{*}$ we convert the ML/AP aspect ratio to the AP/ML aspect ratio in order to compare with data from other studies from ASIA (see Table IV).
The relationship of AP medial and AP lateral with ML dimension as demonstrated in Table II shows a significant positive and weak linear relationship between AP medial and ML $(r=0.475 ; \mathrm{p}<0.001)$ and a similar relationship between AP lateral and $\mathrm{ML}$ as well ( $\mathrm{r}=0.521$; $\mathrm{p}<0.001)$. From this, we can deduce that with increasing AP length, the ML width increases but with a smaller magnitude. When comparing AP medial and lateral, the correlation between AP lateral and ML was slightly better.

Table II. Correlation of AP and ML of the measured distal femur among female patients with current TKA prosthesis $(n=207)$.

\begin{tabular}{lll}
\hline Variable & ML & \\
\cline { 2 - 3 } & $\mathrm{r}$ & $p$-value 1 \\
\hline AP Medial & 0.475 & $<0.001$ \\
AP Lateral & 0.521 & $<0.001$ \\
\hline
\end{tabular}

$\mathrm{AP}=$ Anteroposterior; $\mathrm{ML}=$ mediolateral; $\mathrm{r}=$ correlation coefficient 12-tailed correlation test were applied.

In terms of ML mismatch, there was significant difference between the mean ML width of the resected femur with that of the component $(\mathrm{p}<0.01)$. The average component overhang was $2.11 \mathrm{~mm}$ (Table III). ML dimension of the femoral component increases in close approximation with the morphological data. Despite that, for a given AP length, the ML dimension of the femoral component tend to be wider. By extrapolation of the best fit line for the morphological data, the disparity between them is expected to be more pronounced in the larger knees (Fig. 2).

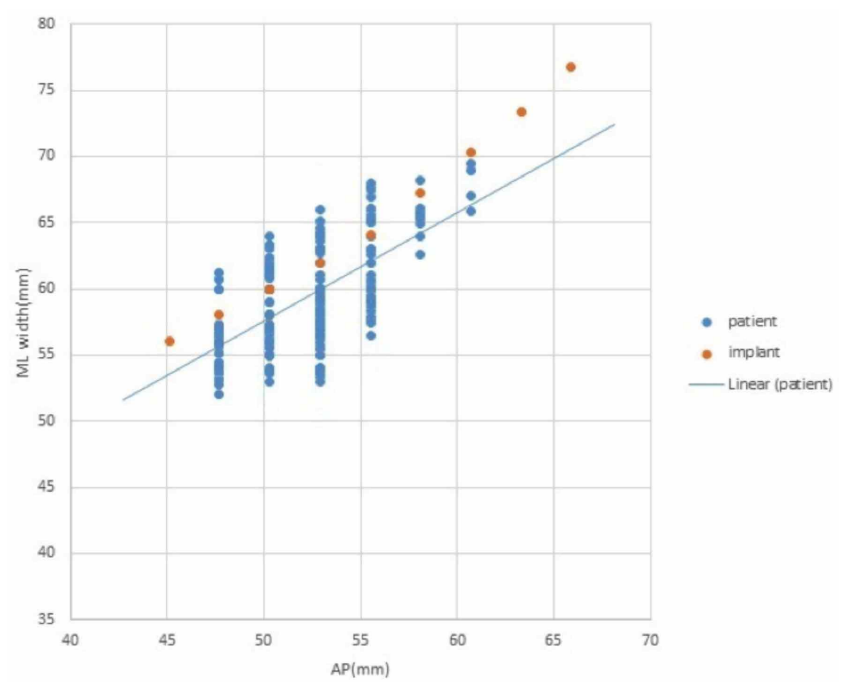

Fig. 2. The femoral medial-lateral width (M/L) versus the given anterior-posterior (A/P) span of implant sizes in 207 female patients.

The calculated mean aspect ratio of the morphological data as determined by ratio of ML to APM and APL were 0.91 and 0.88 , respectively. The aspect ratio 
for the morphological data showed a larger ratio for smaller knees and inversely a smaller ratio for larger knees.Regardless, the best fit line for the aspect ratio of the morphological data was seen to be generally smaller than the implant aspect ratio. Despite the discrepancy, the initial five sizes of the implant did show changes in its aspect ratio which tends to follow the trend of the morphological data. However, the larger implant sizes used at our center, show little change in its aspect ratio, hence widening the margin of difference (Fig. 3). Thus, the implant ML overhang is expected to be more prominent in the larger knees.

\section{DISCUSSION}

Issue on implant sizing which match the morphology of distal femur has always been a great field of research. Worldwide, various studies have been conducted to analyze the morphology of the distal femur and correlating them with the TKA prosthesis in use. Of note, various study designs ranging from studies involving plain radiographs to CT or MR imaging, cadaveric as well as intraoperative measurements have been identified in our wide literature search (Hitt et al.; Ho et al., 2006; Yue et al.; Cheng et al.; Ha \& Na, 2012; Thilak \& George). We believe that intraoperative measurements of pathologic knees such as in osteoarthritis are more direct, practical and representative of the actual morphology of the native femur that requires TKA.

Component overhang in our female population was notably more prominent in the larger knees. This finding is consistent with the description by Hitt et al . in their female population. As compared to their study, ours revealed a smaller magnitude of implant overhang ( $2.1 \mathrm{~mm}$ vs 4.9 $\mathrm{mm})$, Although smaller, this ML mismatch of the implant with the morphological data has proven to be statistically significant $(p<0.01)$. As in our study series, the femoral components used were predominantly from the lower half of the available sizes. Thus, we could get away with lower magnitude of implant overhang. If we were to encounter larger knees, we expect to deal with a wider margin of overhang and its associated complications.

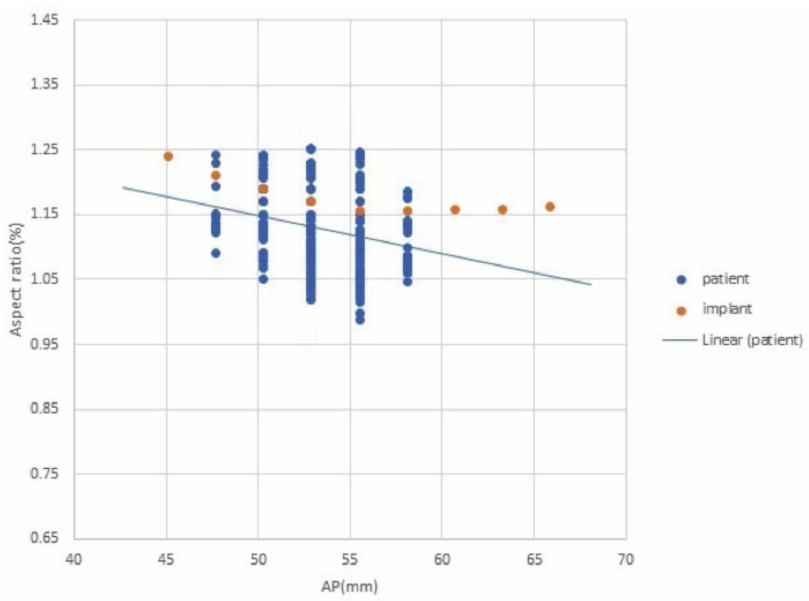

Fig. 3. The femoral aspect ratio (ML/AP) versus the anterior-posterior (A/P) measurements for 207 female knees in comparison with the currently used implant sizes.

The aspect ratio of the morphological data in our study were generally smaller than the aspect ratio of the implant currently in use for any given AP dimension. Nevertheless, the initial five sizes of the implant did show changes in its aspect ratio which tends to follow the morphological data. However, the larger implant sizes showed little change in its aspect ratio. This is contrary to the findings in several other studies (Hitt et al.; Ho et al.; Ewe et al.) which showed little changes in all the implant sizes of the various designs evaluated. Although our morphological aspect ratio follows the implant aspect ratio quite closely, we still have significant ML overhang in our study.

In general, many studies have shown that females have narrower distal femurs than male counterparts and the Asian distal femurs are generally narrower than the Caucasians (Vaidya et al.; Urabe et al.; Chin et al., 2011; Yue et al.). Interestingly, the knees of our sub-population are noted to be even narrower than the Singaporeans (Chin et al., 2011), the Koreans ( $\mathrm{Ha} \& \mathrm{Na}$ ) or the Thais (Wanitcharoenporn et al., 2014) (Table IV). Thus, in general, for any given implant size, our population is at a greater risk of ML overhang. This justifies the need for specifically tailored implant design with a smaller ML width for a given AP length to suit the morphology of our female population.

Table III. Comparison of ML between the measured distal femur of subjects and components among female patients with current TKA prosthesis $(n=207)$.

\begin{tabular}{llllll}
\hline Variables & Subjects femur & $\begin{array}{l}\text { Femoral } \\
\text { component }\end{array}$ & $\begin{array}{l}\text { Mean difference } \\
(95 \% \mathrm{CI})\end{array}$ & t-statistic (df) & $p$-valuel \\
\hline ML dimension $(\mathrm{mm})$ & $\begin{array}{l}\text { Mean(SD) } \\
59.61(4.33)\end{array}$ & $61.73(1.75)$ & $-2.11(-2.88,-1.36)$ & $-5.51(206)$ & $<0.001$ \\
\hline
\end{tabular}

\footnotetext{
$\mathrm{ML}=$ mediolateral. 1 Independent $\mathrm{t}$-test was applied.
} 
AB RAHMAN, S.; RADHAKRISHNAN, S.; SHOKRI, A. A.; AHMAD, M. R.; ISMAIL, A. F.; HASHIM, H. A. \& MUZAFFAR, T. Morphology of intraoperative measurement of distal femur in Northern Malaysian females and its correlation with total knee arthroplasty implant sizing. Int. J. Morphol., 39(1):192-197, 2021.

Table IV. Comparison in data obtained from intra-operative measurements of distal femurs in female patients from various Asian countries.

\begin{tabular}{lcccc}
\hline $\begin{array}{l}\text { Studies } \\
(\mathrm{n}=\text { sample size })\end{array}$ & $\begin{array}{c}\text { Current study } \\
\mathrm{n}=207\end{array}$ & $\begin{array}{c}\text { Chin } \text { et al. } \\
\mathrm{n}=290\end{array}$ & $\begin{array}{c}\text { Wanitchareonporn } \text { et al. } \\
n=170\end{array}$ & $\begin{array}{c}\text { Ha } \text { et al. } \\
\mathrm{n}=678\end{array}$ \\
\hline Countries & Malaysia & Singapore & Thailand & Korea \\
APM $(\mathrm{mm})$ & $65.74(57.3-74.9)$ & $68.1(60.5-77.5)$ & $53.6(46.1-66.0)$ & $61.4(54-76)$ \\
APL $(\mathrm{mm})$ & $67.86(58.8-75.5)$ & $66.5(57.5-75.5)$ & $51.6(44.2-62.3)$ & $60.8(54-77)$ \\
ML $(\mathrm{mm})$ & $59.61(50.1-70.2)$ & $63.0(51.0-77.0)$ & $64.7(56.0-77.0)$ & $68.2(58-73)$ \\
APM/ML & $1.11(0.94-1.36)$ & $1.09(0.92-1.39)$ & $0.83(0.69-0.94)$ & $0.90(0.79-1.06)$ \\
APL/ML & $1.13(0.97-1.39)$ & $1.06(0.89-1.36)$ & $0.80(0.68-0.91)$ & $0.89(0.83-0.95)$ \\
\hline
\end{tabular}

The value is presented in mean (range).

The weak positive relationship between the APlength and ML width as demonstrated in our study population signifies that the ML dimension increases in a smaller magnitude as the AP increases. Thus, implant sizes should be tailored to accommodate a smaller change in ML for an increment in the AP to get a better fitting prosthesis hence curbing the problem of ML overhang. The variation in the morphology of our population and its difference from other population should be considered for a specific implant design. One author suggested that implant component should be designed with several medial-lateral widths for one anterior-posterior length to obtain a better anatomical fit as it was founded that patients with approximately equal AP dimension may have a different ML width (Ho et al.).

We believe that, implants should be designed based on the morphological data of the local population. As revealed in our study that the currently used implant is broader than our morphological data, it poses risk of soft tissue irritation and may affect balancing (Hitt et al.). Further research in this field with regards to evaluating the long-term outcome of patients with implant overhang should be undertaken in near future to determine its impact to our population.

\section{CONCLUSION}

We conclude that the currently used implant is suboptimal in its sizing for our population as depicted by the disparity in the aspect ratio and ML length for given AP dimension, notably in the larger sizes. The results of this study could provide a guide to implant manufacturers to tailor implants which suit the morphometric measurements of Malaysian population especially in female patients hence maximizing the outcome of TKA and reducing its complications.

ACKNOWLEDGEMENTS. This project is supported by the Research University (RU) grant of Universiti Sains Malaysia (Grant no. 1001/PPSP/8012312).
AB RAHMAN, S.; RADHAKRISHNAN, S.; SHOKRI, A. A.; AHMAD, M. R.; ISMAIL, A. F.; HASHIM, H. A. \& MUZAFFAR，T. Morfología única de la medición intraoperatoria del fémur distal en mujeres del norte de Malasia y su correlación con el tamaño del implante en artroplastía total de rodilla. Int. J. Morphol., 39(1):192-197, 2021.

RESUMEN: El tamaño exacto del implante es uno de los principales determinantes para definir el éxito de la artroplastía total de rodilla (ATR). Los implantes de TKA se basan en la morfometría de rodilla caucásica, cuyo tamaño está reportado como mayor que las rodillas asiáticas. Más aún, en lo que respecta al tamaño, el desajuste de los implantes tiende a ser más evidente en la población femenina. Este estudio fue diseñado para evaluar las dimensiones del fémur distal de pacientes mujeres malasias que se sometieron a ATR en nuestra institución y compararlas con el sistema protésico actual. En este estudio se incluyeron un total de 199 pacientes (207 rodillas) que se sometieron a ATR. Intraoperatoriamente, se midieron las dimensiones AP (cóndilos medial y lateral) y el ancho mediolateral (ML). Se comparó la dimensión conocida del componente femoral del sistema protésico de rodilla actualmente en uso con los datos morfológicos. El voladizo o sobresaliencia del componente femoral fue de 2,11 mm (DE 3,94 mm). Hubo una diferencia significativa entre el ancho ML medio del fémur resecado y el componente femoral $(\mathrm{p}<0,01)$. El análisis también reveló una relación significativa positiva y débil entre las dimensiones AP (medial y lateral) y ML. La relación de aspecto (ML / AP) del fémur nativo fue más pequeña que la relación de aspecto del implante, lo que probablemente cause un voladizo en nuestra población. En general, este estudio muestra que las rodillas de nuestra subpoblación femenina son incluso más estrechas que otras rodillas de mujeres asiáticas reportadas en estudios anteriores. Los implantes deben ser diseñados en base a los datos morfológicos de la población local. Los fabricantes de implantes deben adaptarlos a un cambio más pequeño en el ancho de ML para un incremento en la longitud AP y proporcionar varios anchos ML para una longitud AP con el objetivo de obtener una prótesis de mejor ajuste y frenar el problema del voladizo ML.

PALABRAS CLAVE: Medición morfométrica; Rodillas femeninas de Malasia; Artroplastia total de rodilla; Dimensiones de rodilla. 


\section{REFERENCES}

Cheng, F. B.; Ji, X. F.; Lai, Y.; Feng, J. C.; Zheng, W. X.; Sun, Y. F.; Fu, Y. W. \& Li, Y. Q. Three dimensional morphometry of the knee to design the total knee arthroplasty for Chinese population. Knee, 16(5):341-7, 2009.

Chin, K. R.; Dalury, D. F.; Zurakowski, D. \& Scott, R. D. Intraoperative measurements of male and female distal femurs during primary total knee arthroplasty. J. Knee Surg., 15(4):213-7, 2002.

Chin, P. L.; Tey, T. T.; Ibrahim, M. Y. B.; Chia, S. L.; Yeo, S. J. \& Lo, N. N. Intraoperative morphometric study of gender differences in Asian femurs. J. Arthroplasty, 26(7):984-8, 2011.

Ewe, T. W.; Ang, H. L.; Chee, E. K. \& Ng, W. M. An analysis of the relationship between the morphometry of the distal femur, and total knee arthroplasty implant design. Malays. Orthop. J., 3(2):24-28, 2009.

Ha, C. W. \& Na, S. E. The correctness of fit of current total knee prostheses compared with intra-operative anthropometric measurements in Korean knees. J. Bone Joint Surg. Br., 94(5):638-41, 2012.

Hitt, K.; Shurman 2nd, J. R.; Greene, K.; McCarthy, J.; Moskal, J.; Hoeman, T. \& Mont, M. A. Anthropometric measurements of the human knee: correlation to the sizing of current knee arthroplasty systems. J. Bone Joint Surg. Am., 85-A Suppl. 4:115-22, 2003.

Ho, W. P.; Cheng, C. K. \& Liau, J. J. Morphometrical measurements of resected surface of femurs in Chinese knees: correlation to the sizing of current femoral implants. Knee, 13(1):12-4, 2006.

Ismail, M. S. M. E.; Sharifudin, M. A.; Shokri, A. A. \& Ab Rahman, S. Preoperative physiotherapy and short-term functional outcomes of primary total knee arthroplasty. Singapore Med. J., 57(3):138-43, 2016.

Lonner, J. H.; Jasko, J. G. \& Thomas, B. S. Anthropomorphic differences between the distal femora of men and women. Clin. Orthop. Relat. Res., 466(11):2724-9, 2008.

Magetsari, R.; Suyitno; Dharmastiti, R.; Salim, U. A.; Hidayat, L.; Yudiman, T.; Lanodiyu, Z. A. \& Dewo, P. Three dimensional morphometry of distal femur to design knee prosthesis for Indonesian population. Int. J. Morphol., 33(4):1255-60, 2015.

Seedhom, B. B.; Longton, E. B.; Wright, V. \& Dowson, D. Dimensions of the knee. Radiographic and autopsy study of sizes required by a knee prosthesis. Ann. Rheum. Dis., 31(1):54-8, 1972.

Thilak, J. \& George, M. J. Patient - implant dimension mismatch in total knee arthroplasty: Is it worth worrying? An Indian scenario. Indian J. Orthop., 50(5):512-7, 2016.

Urabe, K.; Mahoney, O. M.; Mabuchi, K. \& Itoman, M. Morphologic differences of the distal femur between Caucasian and Japanese women. J. Orthop. Surg. (Hong Kong), 16(3):312-5, 2008.

Vaidya, S. V.; Ranawat, C. S.; Aroojis, A. \& Laud, N. S. Anthropometric measurements to design total knee prostheses for the Indian population. J. Arthroplasty, 15(1):79-85, 2000.

Wanitcharoenporn, W.; Chareancholvanich, K. \& Pornrattanamaneewong, C. Correlation of intraoperative anthropometric measurement of resected Thai distal femurs between unisex and gender-specific implants. J. Med. Assoc. Thai., 97(12):1308-13, 2014.

Yue, B.; Varadarajan, K. M.; Ai, S.; Tang, T.; Rubash, H. E. \& Li, G. Differences of knee anthropometry between Chinese and white men and women. J. Arthroplasty, 26(1):124-30, 2011.

\author{
Corresponding author: \\ Dr Shaifuzain Ab Rahman \\ Senior Orthopedic Lecturer \& Arthroplasty Consultant \\ Department of Orthopaedics \& Traumatology \\ School of Medical Sciences \\ Health Campus \\ Universiti Sains Malaysia \\ 16150 Kubang Kerian \\ Kelantan Darul Naim \\ MALAYSIA
}

Email: shaifuzain@usm.my

Received: 21-06-2020

Accepted: 09-09-2020 